\title{
D I S A R M THE INFAMOUS THING
}

Gayle K. Horii

The experience of imprisonment has both humbled and enriched me, albeit through pain and suffering. In commenting on the needs and experiences of women in prison I can only provide my subjective perspective, for though I am a woman who has survived prison, the experiences are deeply personal. We are all unique individuals, those inside the walls and those outside the walls.

However, despite the distinctiveness of our perspectives and experiences I believe we meet in common purpose - and that is to begin the means to end VIOLENCE in our society under law. But first we must understand what it is that we are up against, how violence is nurtured and how it grows - the factors which create violence. And, though prisons may be just one factor legitimizing ongoing violence, they are never-the-less, a factor overlooked. As a woman incarcerated for three years with all women and then for four years with all men, I am in a unique position to comment on these violent places of anguish.

I was incarcerated for seven years, for the killing of my step-mother, an act of extreme violence. I mourn this heinous deed, and if I thought doing more time could undo this horrendous act or would make the world a safer place I would voluntarily return to prison. But I cannot return Anna's life and imprisonment does not lessen the violence in society. I know what enables violence and I'd like to devote the rest of my life to saving women from tragedy. However, while in prison, I was not able to save any woman, or, it seems, to lessen the brutality of imprisonment -- "the exercise of the power of consent over another person" (Shafer \& Frye 1977:290) - the definition of rape.

I feel it ironic, that while incarcerated for a violent crime, I witnessed and was surrounded by death and violence inflicted both by staff and by prisoners, none of which I was able to stop and in fact, which I was forced to endure. For the last four years of my incarceration I was kept in the Matsqui Prison Hospital alongside male prisoners ill and dying. During my four years there, five men died. I breathed every dying breath with the last two men. Over my seven year imprisonment, I knew twelve women and twelve men who died while in prison or very shortly after release. Nine of these twenty-four deaths were by suicide, seven of these suicides were by women. Five of the seven were Native women.

The most publicized suicide was that of ninety pound MARLENE MOORE, or Shaggy as she liked to be called. I remember her gaunt arrival at Prison for Women (P4W) in Kingston, April, 1988. Unsteady on her feet and banging into furniture, she said she had no glasses and couldn't see. Her arms were masses of scar tissue stretched taut over bone and when I looked at her, the pain-filled pools that were her eyes, imprinted on my heart. She wound up in a fight that first day, in the dining room after butting her cigarette into what she thought was a black 
ashtray. It turned out to be someone's black plastic salad bowl. They both went to the segregation. From that day on Shaggy was rarely in regular population. She usually ended up in the hole when she couldn't wait any longer for the nurses to catheterize her. When she was in so much pain and feeling so shamed, she would act out and often she would slash herself.

On the night of Nov.24, 1988, four women attempted hanging in segregation. Shaggy coped the only way she knew. She slashed herself unmercifully. P4W's treatment for her slashing was to build a 7' X 12' plexi-glass partition to slide in front of her cage, so she couldn't throw her blood out at the guards.

These are excerpts of Shaggy's last note, the end of November, 1988:

...I ain't doin so good...i'm wetting all over...i feel like shit ....I got 40 days....they had the hoses out....juss becuz I slashed - well this is getting me down pissen all over the place...so after the cops got prepared to hose me down $\&$ there all in space suits and crash helmets $i$ said ill walk....we been in here since the beginning of October....i dont no what i'm doing i'm reely fucked up over whats been happenen in here...sorry you guys $\mathrm{i}$ dont mean to wet i cant stop bag or no bag i'm reely embarrest ashamed. hurt. i began to hate myself ya no. cuz $i$ think whod want a person like me around you no what $i$ mean....but remember $i$ love and miss all you guys and i'm reely sorry for keep screwing up. $i$ even hung myself...i got a rope bern reely bad around my neck. be cool. with much love and respect always your buddy shaggie."

One week later, Marlene Moore, was dead. She choked herself to death by hanging off the hospital bed and twisting a sheet around and around her neck. Here is the legitimization of that "treatment":

Kingston Coroner, Dr. Clifford Meyer, commenting at the inquest into Marlene's death said that, "Prison for Women was not at fault in Ms. Moore's death - indeed, it was to be commended."

The jury said, "... it was impressed with the care and the resources afforded women in Prison for Women" (Curtis, 1989).

Over the next three years, six more women took their own lives despite the "commendable care and resources offered" them. Pat Bear and Sandy Sayer in 1989, Marie Ledouxe, Careen Daigneault and Johny Neudorf in 1990, and Lorna Jones in 1991. In 1992 another woman was resuscitated after hanging herself in $\mathrm{P} 4 \mathrm{~W}$. All she wanted was to be incarcerated 2,500 miles to the west, in her home province of Alberta.

If calculated per 100,000 , for the years 1988 to 1991 , the annual rate of suicide at P4W would have ranged from 869 to 2,609 per 100,000 women prisoners. Remember - this carnage does not include the

${ }^{*}$ See letters of Marlene Moore in this issue. 
unknown suicides of women in provincial custody. Compare this with the rate of suicide for other Canadian women. The annual suicide rate per 100,000 women in Canada for the years 1960 until 1985 ranged from three to under eight women (Health \& Welfare 1986:31, 82). To be a women imprisoned at $\mathrm{P} 4 \mathrm{~W}$ can translate to the fact that you would be at least 289 times more likely to kill yourself, as you would be if you were free.

You may think that everything is alright now that $\mathrm{P} 4 \mathrm{~W}$ is being shut down, but what did it take to do that? Was it the seven suicides or the public outcry? And how many more suicides will occur before September 1994 as the C.S.C. spend every cent to refurbish P4W for the older male prisoners who will occupy it: P4W dollars unavailable for women so that even the most basic of "programs" are denied to them. P4W is now even worse than when I left it - now a double-bunked warehouse and an abattoir. How many suicides will occur in the new P4W in Burnaby, B.C.? There have already been three serious attempts there that I know of at present. And, how many suicides will occur in the five new P4W's now scheduled to be built? Where will the women now incarcerated at $\mathrm{P} 4 \mathrm{~W}$ go when the aging men imprisoned in Eastern Canada are transferred there? The answer is definitively to even more barbaric places - to provincial jails where slashing is still treated as an "attention-getting" manipulation of authority and where national suicide statistics are unknown.

I used to be suicidal, attempting three times to take my own life, but I have finally recovered through intensive therapy with a woman psychologist. I was raised in a violent home, so violent that even when I was left for dead on the blood-soaked landing of the skating rink, after being raped by a stranger when I was not yet five years old, I was afraid to tell my parents. And I was ashamed to tell anyone else. I was still too ashamed to tell anyone when at eighteen I was drugged at a party and awoke naked, face down and in pain, or at nineteen when I was dateraped by a lawyer, or at twenty-six when I was raped by a politician when I was showing real estate, or at twenty-seven when I applied for a job from a well-respected restaurateur. I masked the fear and the rage with which I lived. I was schooled in violence, and when I committed a violent act, I was punished with violent means by violent people. I know that: VIOLENCE results from the exploitation of POWER imbalances and the SUPPRESSION of the pain of being exploited OFTEN results in more violence which forms the ONGOING CYCLE OF VIOLENCE.

In his 1637 Discourse on Methods, Descartes said that one "must learn to master one's emotions, to keep them subdued" (Gay, 1973). In prison, women are forced to "master" their emotions, and when they do, they slash themselves and hang themselves as Marlene Moore did. Or they go mad as a Toronto woman did, eventually eating her own faeces and menstrual blood before I was finally able, on December 23, 1988 to 
contact Member of Parliament, Svend J.Robinson. Svend intervened to save her life. CM had been naked in the hole at P4W in freezing temperatures for nearly three weeks. This was her "treatment" for being a schizophrenic woman in prison.

Treatment/punishment for breaches to power relationships is a reactive function. Those who are in power determine what is an offence and to what extent punishment/treatment will be imposed. You may say that prisoners are violent and need to be controlled for the safety of the staff. However, while twenty-five prison staff lost their lives on duty in the years from 1870 to 1994 in Canada - a period of 124 years, recent data bears out the facts that at least one federal prisoner will commit suicide every twenty-seven days. This is a ratio of 1:67 staff deaths to prisoner suicides.

I calculated a brief comparison of the rate of harm to staff versus the rate of harm to prisoners for the years 1982 until 1988 with statistics taken from the Annual General Reports of the Solicitor General. The rate of harm to staff remained at 1.3 incidents per 100 staff members while the prison population increased $17.7 \%$. Total incidents of harm to prisoners increased $26.9 \%$, while staff actually experienced a decrease in harm of $6.9 \%$. However, the use of force (mace \& guns) against the prisoner increased by $133.7 \%$. This data suggests that more force is being used against prisoners than ever before.

No statistics are available to account for violence against women in prison, but we do know that no staff member or prisoner has ever been killed in a women's prison in Canada. None of the twenty-nine men's maximum and medium security penitentiaries can boast that record of prison worker safety. Why then are women held in such extreme maximum security conditions and treated so cruelly? It appears that the mere idea of women decidedly breaking the law threatens the status quo the image of mom and apple pie. We must be witches. We must be deviant and we must be punished. Like the men, the punishment begins by stripping the identity from the person. We become females, not women. All become "inmates" or "offenders" - the "others" - the process that enables all discrimination which in turn rationalizes annihilation.

"Evil is anyone outside the tribe. Evil works by dehumanizing the other. A perverse, efficient logic works. Identifying others as evil justifies all further evil against them" (Morrow 1991:50).

The dehumanization of the object group using language, is the first order of prison control.

As Camille Paglia (1991:5) stated, "To name is to know; to know is to control". Knowledge of the subject promotes the legal and human "objective" science of imprisonment which has as its stated goal, the "normalization of people so they can take their 'rightful' places in society" (Foucault 1977). But how can you "normalize" people by 
locking up "inmates" in cages? The subtle use of institutional language softens the cruel reality: self-abuse for slashing; institution for penitentiary; inmate for prisoner; go home, for go to your cage; treatment for punishment. The most respected prison abolitionist, Claire Culhane, unmasks just one correctional aphorism - the description of "inmates (a like-group) feeding" (how animals eat), rather than stating prisoners (who are people locked up against their will), are eating.

In 1991 in Saskatchewan Penitentiary, two prisoners on their knees from the effects of tear gas died from bullets fired into their backs. This is called legal intervention.

On November 1, 1992, parliament passed Bill C-36 ensuring that more prisoners will be incarcerated for longer periods of time than ever before in Canadian history. It is rationalized that conditions are however, humane, and further that - extensive rehabilitation programs are provided. The 1989-1990 Annual General Report of the Solicitor General claims that only 409 man-years are expended in guarding "inmates". The other 3,193 former guards are now "program deliverers" and though are newly classified under case management, they still wear the uniforms of guards. "Recreational officers" remain prime candidates for the Emergency Response Teams, those infamous groups of blackcostumed and hooded men who beat naked and unarmed prisoners as they "resist" cell "extractions".

Similar to corporations and governments who hide their foul deeds of pollution, exploitation and corruption behind their sterile entity logos, using smooth public relations managers, prison regimes hide their foul deeds behind the authority granted to them under the law couched in sophisticated public relations language. The Conservative government chose a top firm, The McLaughlin Group, to sell the Free Trade Agreement, the NAFTA and the GATT, a contract worth $\$ 842,000$ (Langlois, 1992:15120). The CSC uses the same firm to control what is reported to the media. I don't know how much it costs the C.S.C. to mask the violence of punishment.

It has already been proven that excessive punishment does not change poor behaviour, rather, that it builds deep-seated resentment. The longer a person is prevented from normal socialization, and remains under the extremes of control, the greater is the alienation and estrangement from their society. When an ex-con returns to society and commits another violent act, the public demands to know why the prisoner was released. NO ONE ASKS what happened to that person before they came to prison or how many prison terms they had served and under what conditions. Is it possible that the costs of the prison environment encompass the creation of sociopaths and psychopaths among both the kept and the keepers?

Just as the German Nuremburg Laws of 1935 served to alienate Jewish people from their rights as citizens and legitimize their status as 
others, so too do legal convictions legitimize the beatings, the macings, the "cell extractions" by hooded and armed men, the use of dogs as weapons of terror and the psychological rape of strip-searching - all under the guise of the "good order of the institution". This is NOT the good order of society but many prisoners with histories of beatings in juvenile detention centres, police and RCMP lock-ups, and finally in provincial and federal penitentiaries have been "taught" that violence $\underline{I S}$ a legitimate response. Additionally, the response of violence is too often associated with "ethnicity".

Corrections Canada will tell you how they respect ethnic values. Their proof is the appointment of the Caucasian daughter of a National Parole Board member to the "Female and Native Offenders" branch. Many questions are begged. How can a privileged Caucasian woman from a career "corrections" family be cognizant of the reality of Native prisoners, men or women? Does this appointment suggest that Native prisoners and prisoners who are female have something in common? Other than both being among the most severely disempowered, there is no other link. Race of the "offender" is itemized in Basic Facts (199192:34) however, no such statistic is available with regard to staffing. The "over-representation" of "ethnic" peoples incarcerated is pandemic. Consider the following:

In Hungary, "Gypsies" constitute 2-3\% of the general population, but $30 \%$ of the prison population and $80 \%$ of the closed prison (maximum) population; In New Zealand, Maoris account for $10 \%$ of the general population, however $50 \%$ of the prison population; In Canada, Aboriginals constitute only $2 \%$ of the general population but $16 \%-60 \%$ of the prison population depending upon jurisdiction (Penal Reform International, September 1991. The Alternative Target).

As a principal of a Bedouin school stated in the summer of 1985, "... if it was not enough what they [Israeli state] are doing to us, now they tell us we are an ethnic group" (Nordstrom and Martin 1992:85). Ethnicity is a term used by the dominant hegemonic culture, a colonial and imperialist way of coming to terms with the "others". The oldest inhabitants of Canada, the peoples of the First Nations, are an "ethnic" group over-represented in Canadian prison populations, a group whose "ethnic needs" are among the first to suffer from the axe of budgetary cutbacks.

The reduction of sweat lodge participation is rationalized by the high cost of wood. This is just one reality antithetical to the "ethnic" policies of Corrections Canada. The sweat lodge and the Native Elder participation have become mere romanticizations as Native life skills programs are cancelled or run by non-Native correctional staff. "Ethnic" valuations are cherished myths shoring up the censored canvases of the condemned. The denigration of the First Nations' peoples is violence in 
its most insidious form, but it is the structure of imprisonment itself, which enables it to continue. Law is a process by which government structures choice.

Another form of violence, covertly applied, is discrimination against women. Told that university education and private family visiting was available at P4W, I made the impossible choice to serve my time 3,000 miles from my family in B.C. A man in a similar situation would never have had to make that decision. When I found my security level bumped up to comply with $\mathrm{P} 4 \mathrm{~W}$ policy which effectively blocked my attempts for education and for return to my home province, I was in despair. I felt powerless and stupid because I had no knowledge about prisons or about criminal or prison law. I had made a decision based only on what I was told and decided that I had better educate myself so that any further decisions I may make would be based on, in the least, the best information I could find.

When I arrived at P4W in 1986, we had no hot water or cablevision in the cells. I grieved both. On October 29, 1987, the hot water was finally turned on. It had always been available. Why would men be given access to hot water and not women? Is it due to the belief that women would still keep themselves clean, even if all they had was ice cold water but more insidiously because of the belief that women should be punished more severely than men? At P4W, cablevision was installed in 1988. Men in prison had cablevision for over ten years prior to that. However, men are a control problem and having them quietly watching the tube helps to keep the prison atmosphere pacified. Women are rarely a control problem.

Besides the documented inequality of facilities and programs, socialization and visiting rights, facilities where cell decoration, cooking for oneself, and outdoor facilities provide tennis and golf for men, the discrimination reaches to cover the most basic of conditions for incarcerated women. We must buy shampoo and laundry soap, while men are issued these necessities. We are not issued outdoor clothing while men are. Mind you, women in prison receive little time for fresh air and gym activities compared to the men who have full gyms and yards open to them twelve hours a day except for work days. Why is exercise not considered essential for women? Again, is it just part of the "status quo" control model which still furthers the out-of-date philosophy that participation in sports is not lady-like?

At Prison for Women in 1986, we were permitted one ten-minute phone call per month. In contrast, men incarcerated in B.C. (usually their home province) were permitted up to 100 minutes of phone time per month. This amounts to 10 times the contact allowed women at P4W, many of whom were thousands of miles from their families. After petitioning, phones were installed in 1988. Though THE CHARTER guarantees equality under the law, the infamous abattoir, Prison for 
Women stands as a monument and an example of the brutal reality imposed upon the most helpless population in Canada, the population of women imprisoned. And now, the Burnaby P4W and the new regional P4W's will be the new dark monuments to this same lie.

In Burnaby in 1990, a woman who requested a copy of the Exchange of Services agreement was put in the hole and remained there until her release date. The Canadian Association of Elizabeth Fry Societies' (CAEFS) Newsletter which included writings from other women inside, (including myself), and which gave women instructions on how to obtain their legal rights, was never permitted inside these walls. Censorship, though unlawful, is clearly the policy at the Burnaby P4W. In provincial custody, women have no access to the Correctional Investigator's office and little knowledge of their legal rights. In women's prisons only very limited access to law books is available, while in men's prisons there are often complete law libraries.

The "open custody unit" in the Burnaby P4W which, quote, "mirrors men's minimum security", is a sham. Just one of the many discrepancies is the visiting where Women at the Burnaby P4W are permitted two one hour visits per week in an enclosed room with no refreshments in a prison which is not served by public transportation. Men in minimum security, may have unlimited all day visits from their children, wives, friends and even the family dog, as long as he is on a leash! Men may have bar-b-q's with their families, go for walks in the forest, or play golf or tennis. The "women" at Burnaby's P4W can roller skate- with each other! The facts are clear - prison authorities simply do not fear women and believe they need not provide women with any "amenities".

Women in prison are juvenilized and our realities trivialized. We are still called "girls" and rarely mothers. Yet it was "estimated that in 1983 alone, approximately 2,700 women admitted to Canadian jails and prisons were separated from their children, affecting at least 5,400 children and an additional 360 newborn infants" (Faith 1991:167-8).

My refusal to be treated like a "girl" resulted in the province of B.C. denying my return seven times. I fasted and overwhelming community support forced the CSC to save my life and return me to B.C. Ironically, only because I was imprisoned in a men's penitentiary did I have the opportunity to attend university classes. Since my release on day parole, I have completed the final requirements for a degree in Anthropology which was conferred in June. Women need education. If I had been in the Burnaby P4W, I would have been training dogs with behaviour problems. I would not even be considered worthy enough to train just any dog, I would be worthy of training only dogs that bite!!.

As far as the treatment of women convicted of crime, most things haven't changed. The first lawful hanging in Canada was that of a sixteen year old French Canadian girl convicted of robbery. Her execution was carried out by a male convict also sentenced to hanging 
but given his life in exchange for this 'duty' no other would do. However, in 1640, this very young woman was not yet a legal person. She had no rights whatsoever, yet had the same punishment imposed upon her. She would have become a person on Oct.20, 1929, nearly three hundred years later. So, in 1640 a woman could be hanged for threatening the status quo, but never achieve any of the protections afforded to that male sphere.

In 1789, following the French Revolution - the Declaration of the Rights of Man became law. Yet, just two years later,- Olympe de Gouges, a woman, was guillotined for writing "The Rights of Women" ("les Droits de la Femme") (Beattie, 1986:602). The feminists of Canada remembered this 200 year old lesson and protected the rights of women here. The Equality provision guarantees equality between individuals before and under the law, and the right for equal protection and equal benefit of the law, without discrimination, and specifically precludes discrimination on the basis of sex.

In 1992 in Canada, feminists again stood strong, and along with the majority of Canadians voted down a Constitution that would have erased many individual rights in favour of group rights of the status quo. It is now 1994, and women still receive similar sentences to that of convicted men, but that is where the equality ends for federally sentenced women. How that sentence is carried out on women is far more harsh and the future looks bleakly unchanged. Though the 1990 Task Force Report on Federally Sentenced Women was intended to change the future for incarcerated women in Canada, the successful obfuscation of the powerful potential of these recommendations can be attributed to the power holders who are masters at masking truth from their own biases and distortions, a "kind of intellectual imperialism" (Clammer 1985:15).

Since all other federally sentenced women in B.C. are under the control of provincial authorities, I am the last federally sentenced woman in B.C. who is a federal responsibility. My court action which challenges the status quo and the lawfulness of the discriminating conditions that women in prison must endure, should be heard in Federal Court this year. We have laws that were designed to protect us from violation in all forms. The grand-MOTHER law, the CHARTER of Rights and Freedoms, the fundamental basis of the 1982 Constitution Act, is where $I$ and all women both inside prison and outside prison must look for justice.

However, how can the guarantees in the Charter be realized as long as we maintain the status quo - the structures of severe power imbalances? Christine Boyle at the Dalhousie Law School concluded that it is primarily fear that keeps people from effectively challenging the status quo (Lahey, 1986:viii). But now, in addition to fear, there is poverty. With the cancellation of the Charter Challenge Funding, effective February 27, 1992, any challengers to inequalities perpetrated 
by governments or agencies or corporations - the status quo - will be unable to proceed. The new Liberal government has promised reinstatement. However no official policy has yet been issued to that effect. Impoverishment, racism and sexism are all forms of violence.

The irony is that the very system which defines discrimination under law is that which permits its' lawless life. Without the Court Challenges program the exorbitant costs associated with a major claim make equal justice prohibitive. At the same time as the Charter Challenge Fund was cancelled, the Justice Minister announced the hiring of more teams of lawyers to defend the government against legal challenges by the individual. Our freedoms appear more at threat from the inside than from the outside!

The $\$ 4.4$ billion dollar Department of National Defense expenditure for helicopters we don't need (Brewin, 1992:14515), could be transferred to the Charter Challenges program. We also desperately need community boards to keep watch over status quo bodies of power. Rotating boards could review all police and corrections areas, provincial and federal, adult and juvenile, men's and women's, ensuring that the law of this land reflects equitable social justice rather than the interests of the powerful, as is the case currently. Now, these bodies investigate themselves. How can the left eye investigate the right eye using only the right eye for vision? The new post-structuralist approach emphasizes the necessity of challenging the questioner and the questions along with the form of inquiry. In Canada, as Ruth Benedict states, "a discourse on forms becomes, confusedly, one on levers" (Geertz 1988:125)!

Recommendations of the Correctional Investigator to right unfair and often brutal practices inside the walls have no force under law. In fact, Bill C-36 expressly states, "Neither the Commissioner nor the Chairperson of the National Parole Board is bound to act on any finding or recommendation made under this section (Part III 179 (3))".

In 1994, the 1977 Correctional Investigator's office remains effectively impotent and still reports to the Solicitor General. The mere presence of this office effectively presents the assumption that prisoners have a path to reconcile wrongs done to them. The reality of course is simply another falsehood; however, paperwork creates jobs. Inquiring into this sorry state, I completed a five year statistical study of unsolved grievances at the fourth and final level of grieving to discover that the same areas of conflict are unresolved year after year. This fact remained unchanged with over 4,000 grievances reaching this fourth level in 1990, about 1 for every 3 federally incarcerated prisoners. The point is that the CSC knows where the problems lie, they simply have no intention of resolving these ongoing conflicts. There is no law which demands that peaceful solutions be a priority.

Violence results from the inability to resolve conflict in a peaceful manner. The reality for prisoners is that violence in prisons promotes 
job security for prison workers. The prison industry is the most secure growth industry in Canada and like the four tombstones, those of Mary Harting 1936, G. Teolis D. 1944, Ada Roy 1894-1941, and D. Dillabough 1919-1966, that lay for decades beneath the gym floor at $\mathrm{P} 4 \mathrm{~W}$, the burgeoning prison industry is an obscene monument to the failure of social justice in Canada. Mention must be made about the few fine people in corrections. I respect their courage in attempting to carry out their duties in a humane and fair fashion. However, even they suffer discrimination from their own peer group and their small numbers are unable to effect meaningful change. In some respects their presence only creates the illusion of "humane corrections", that intervention doesn't necessarily mean using force. The members of the Emergency Response Team prove otherwise.

Eighteenth century theorists decided that prisons could reform and reclaim the individual by "removing the offender from the source of contamination" (Beattie, 1986:569). But instead of reforming the prisoner, prisons immediately became mere cesspools of contamination. As Zimbardo's 1971 Stanford University experiment proved - it is not necessarily the prisoner nor the keeper that makes prison the vile place it is, but rather the structure of the prison regime itself. The structure of laws and policies that endows ordinary people with life and death power over others enables an insidious relationship begging corruption, indignities, entrapments and assaults. Few people can handle power without becoming corrupt, and as Lord Acton stated, "Power corrupts, absolute power, corrupts absolutely".

Penetrating changes in anthropological representations emanate from the 1960s which spawned a general criticism of traditional authority. What emerged in the social sciences was a renewed focus aimed primarily towards the relations and construction of power and knowledge.

Michel Foucault (1979) asked, "How is power exercised?" Well, in prisons, the answer is: the power matrix - observation, surveillance and classification $=$ knowledge of actor $=$ correction $=$ internalization $=$ reformed person. This is the "scientific rationale behind imprisonment", a doctrine of positivism. However, as Josephine Donovan (1986:28) stated "The Newtonian view provides no means of establishing or legitimizing qualities or values. The rule of the majority is a quantitative judgment which ultimately says nothing about the ethical legitimacy of its position".

Institutions do not stop violence. They perpetrate it by eliminating individual freedoms and responsibilities in favour of the power-holders' status-quo-sponsored morality. Discrimination is a rationalized form of violence. "...in every society an ideological order of power, control, and domination" (Therborn 1980:81) exists by reinforcing the concept of the other, those who do not belong. It is through hierarchal institutions that 
the abuse of power is universally and violently perpetrated. And, it is only through consensus-like replacements powered by feminist ideologies and re-education, that the abuses and the violence can be eliminated.

Women could claim equal power now. The formation of a nonpartisan, feminist Shadow Cabinet may provide a beginning. How that is actioned is the key to eliminating violence. A theoretical framework for the analysis of social change must be concerned largely with what happens to social structures. But to be truly dynamic it must allow for individual action (Frankenburg 1967:50).

I have discussed violence, the result of the exploitation of power imbalances and how these severe imbalances of power ensure the growth of violence in our society through the legal and/or political authority that is granted to institutions. I have discussed the exercise of the power of consent over another person - the definition of rape.

We maintain within us thousands of years of genetically inherited memories of violence, memory of the horrors of rape recorded as early as 290 B.C. of the Sabine women, to the ongoing rape and murder of women and children in Bosnia and all over the world at this very minute. Rape is a universally accepted weapon of male wars (Brownmiller 1975).

We know of the "seven centuries of witchcraft-related persecution justified on biblical grounds which tortured, drowned, hanged and burned at the stake as many as "nine million defenceless women" (Faith 1991:210). We know of the hundreds of millions of women over the ages sold into slavery and prostitution, who have had their babies ripped from them, who have been and are being tortured and whose genitalia are disfigured or removed entirely. We know of the impoverished misery, the humiliation and the unbearable agony of the lives of the majority of women around this globe, much of it imposed actively upon them by their own families, their doctors, clergymen, teachers and the courts, all enabled by the institutions that give them membership - the cultural hierarchies and the patriarchal structures of the military, the state, the church and the professions, all self-governing bodies which enable ongoing violence and injustice.

Post-modernism has deconstructed macroprocesses so that the understanding of the lines of division can be made clear and so that the significance of change can be visualized, in particular the social consequences flowing from these larger legitimizations of authority. As Foucault states, the "effects of power are not attributable to appropriation but to functions" (O'Brien 1978:513).

Voltaire popularized the phrase "ecrasez l'infame" (crush the infamous thing) -referring to the stranglehold of the church (Hampson 1990). Feminists would argue that the "thing" is the big one - patriarchy. And I, a woman on parole and a post-modernist feminist would add that the big arms of the big thing, patriarchy, are the institutionalized hierarchal 
structures. If we are to make our world a safer place we must D I S A R M this big thing - patriarchy.

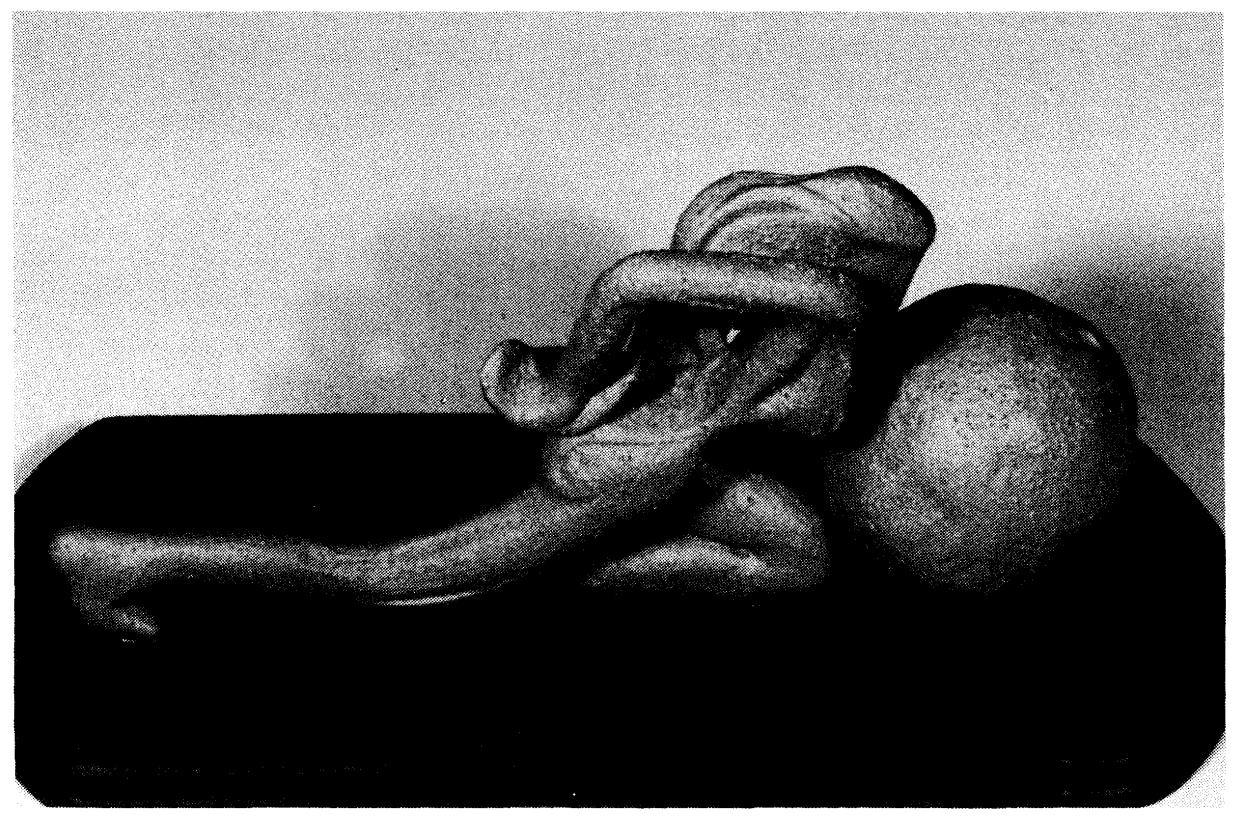

\section{WOMAN'S HEART}

It should be possible to speak of the SUPPLY of prestige, the DEMAND for power and the COST of authority.

- Robbins Burling, 1962 


\section{REFERENCES}

Beattie, J.M. 1986. Crime and the Courts in England 1660-1800. Princeton. Princeton University Press.

Brewin, John. 1992. House of Commons Debates. Ottawa: Hansards. December 15, 1992:14515.

Brownmiller, Susan. 1975. Against Our Will, Men, Women and Rape. New York: Simon and Schuster.

CAEFS, Newsletter. The Canadian Association of Elizabeth Fry Societies: Ottawa.

Caputo et al. 1989. Law and Society. Toronto: Harcourt Brace Jovanovich

Clammer, John. 1985. Anthropology and Political Economy. New York: St. Martin's Press.

Curtis, Dennis. CSC Spokesman, Ontario region. Unpublished comment in a media report sent to media representative.

Department of the Solicitor General of Canada. 1986. Annual Report 1985-86.

Department of the Solicitor General of Canada. 1988. Annual Report 1987-88.

Donovan, Josephine. 1986. Feminist Theory. New York: Frederick Ungar Publishing Co. Inc.

Faith, Karlene. 1991. The Female Offender. Criminology 213. Burnaby, B.C.: Simon Fraser University Continuing Studies.

Foucault, M. 1979. Discipline and Punish: The Birth of the Prison. London.

Frankenburg, Ronald. 1967. "Economic Anthropology: One Anthropologist's View:. Raymond Firth. Ed. Themes in Economic Anthropology. London: Tavistock Publications.

Gay, Peter. ed. 1973. The Enlightenment. New York: Simon and Schuster.

Gauthier, Jean-Robert. 1992. House of Commons Debates. Ottawa: Hansards. April 1, 1992:9154.

Geertz, Clifford. 1988. "Us/Not-Us". Works and Lives. Stanford: Stanford University Press.

Hampson, Norman. 1990. The Enlightenment. Markham: Penguin Books Ltd.

Health and Welfare Canada. 1986. Suicide in Canada. Report of the National Task Force on Suicide in Canada (1960-1985). Ottawa.

Lahey, Kathleen A. et al, Eds. 1986. Canadian Journal of Women and the Law. Vol. 2 No. 1. Ottawa: Canadian Periodical Publishers' Assoc.

Langlois, C.A. 1992. House of Commons Debates. Ottawa: Hansards. December 11, 1992:15120.

Marshall, James D. 1990. "Asking Philosophical Questions About Education: Foucault on Punishment", Educational Philosophy and Theory, Vol. 22, \#2.

Morrow, Lance. 1991. "Evil", Time Magazine, June 10. New York:

Nordstrom, Carolyn and JoAnn Martin. eds. 1992. The Paths to Domination Resistance and Terror. Berkeley: University of California Press.

O'Brien, Patricia. 1978. "Crime and Punishment as Historical Problem". The Journal of Social History. vol. II, No.4, Summer.

Paglia, Camille. 1991. Sexual Personae. New York: Vintage Books.

Penal Reform International. 1991. The Alternative Target.

Shafer, Carolyn M. \& Marilyn Frye. 1977. "Rape and Respect". Feminism and Philosophy. M. Vetterling-Braggin \& F.A. Elliston, Eds., Ottawa: Littlefield

Therborn, Goran. 1980. The Ideology of Power and the Power of Ideology. Trowbridge: Redwood Burn Ltd. 